\title{
KARAKTERISTIK PEMERINTAHAN DUNIA ISLAM ERA ABAD PERTENGAHAN ISLAM
}

\author{
Landy Trisna Abdurrahman \\ bardezz.gz@gmail.com \\ UIN Sunan Kalijaga Yogyakarta
}

\section{Abstrak}

Abad pertengahan Islam adalah kurun waktu abad $13 \mathrm{M}$ hingga 18 M. Era ini sering disebut sebagai era "kemunduran" peradaban Islam. Namun, sebelum menjatuhkan vonis menyematkan label "maju atau mundur", terlebih dahulu harus dipetakan tentang apa yang yang terjadi khususnya dalam bidang pemerintahan pada era tersebut. Meski banyak pencapaian yang tidak semegah pada abad-abad sebelumnya, tetapi pada era ini ada pola dan karakteristik tersendiri yang sangat berpengaruh pada era modern Islam. Terlebih dalam pemerintahan perkembangan konstitusi dan pemerintahan umat Islam. Tulisan ini akan menjawab satu pertanyaan besar tentang bagaimana karakteristik pemerintahan dunia Islam pada era abad pertengahan (13 M-18 M). Artikel ini menggunakan pendekatan sejarah secara kronologis untuk memberikan deskripsi yang runtut sesuai dengan lini waktu yang terjadi pada kurun waktu abad pertengahan Islam. Hasil temuan dalam artikel ini adalah karakteristik pemerintahan dan pemikiran konstitusi pada era abad pertengahan Islam yang cukup mencolok adalah adanya berbagai pergeseran paradigma dalam dunia pemerintahan, meliputi pergeseran paradigma dari desentralisasi menuju disintegrasi, kemudian munculnya dinasti - dinasti yang bercorak kebangsaan, dan juga pergeresan paradigma penerapan konstitusi pada era pertengahan Islam dari integralistik menuju sekuleris.

Kata kunci: Sejarah, Abad Pertengahan Islam, Pemikiran Konstitusi dan Pemerintahan. 
Spiritualis, vol. 4, no. 2, September 2018|177

\section{A. Pembukaan}

Dalam kancah perpolitikan dan pemerintahan, umat Islam memiliki sejarah yang amat panjang dan berliku. Harun Nasution membagi menjadi tiga era sejarah Islam: Era Klasik Islam, $650 \mathrm{M}-$ 1250 M (abad 7 - 13 M), Era Pertengahan Islam (1250 M - 1800 M), dan Era Modern (1800 M - sekarang). ' Secara garis besar, perkembangan peradaban pada Era Pertengahan Islam terbagi menjadi dua, pertama, era kemrosotan pencapaian, yang kedua, era "kejayaan kedua".

Disini, penulis sengaja tidak menyebutkan era modern sebagai zaman kebangkitan, mengingat, terma zaman kebangkitan Islam cukup mendapat kritik keras pada era pemikir kontemporer seperti Abed Al-Jabiri. Bagi Abed Al-Jabiri, proyek kebangkitan Arab-Islam telah dinilai gagal dari berbagai macam sudut pandang. ${ }^{3}$ Pada era klasik, perkembangan Islam sebagai agama dan ajaran hidup yang mempengaruhi sistem sosial, bersamaan dengan itu, tumbuh dan berkembang sistem politik yang dibutuhkannya.

Dalam perkembangannya, terlebih pada era klasik Islam, hubungan antara negara dan Islam telah menjadi hubungan yang sangat mengesankan sepanjang sejarah manusia. ${ }^{4}$ Saat Nabi Muhammad saw. mulai mendirikan pre-state Madinah, lalu dilanjutkan dengan usaha ekspansi wilayah oleh para khalifah setelah Nabi, telah membentuk sebuah peradaban yang susah dicari tandingannya dalam sejarah umat manusia.

Pada era klasik Islam, corak pemikiran yang berkembang adalah corak pemikiran rasional. Permikiran rasional dipengaruhi

${ }^{1}$ Harun Nasution, Islam Rasional. Bandung: Penerbit Mizan, $1995,7$.

${ }^{2}$ Corak kejayaan dunia Islam yang tentunya berbeda dengan kejayaan zaman klasik Islam.

${ }^{3}$ Muhammad Abed Al-Jabiri, Takwiin al-Aql al-Arabi, diterjemahkan menjadi Formasi Nalar Arab, Jogjakarta: IRCISOD, 2014, 149.

${ }^{4}$ Nurcholish Madjid. Agama dan Negara dalam Islam Telaab aras Figh Siyasy Sunni, Kumpulan Antologi Makalah/Artikel Yayasan Paramadina, Jakarta: Penerbit Paramadina, 1995, 588. 
oleh persepsi tentang bagaimana tingginya kedudukan akal seperti terdapat dalam al-Qur'an dan hadist. Corak pemikiran rasional semakin berkembang pada era klasik saat mulai bersentuhan dengan peradaban Yunani. ${ }^{5}$ Meski di peradaban Yunani tidak pernah dikenal agama samawi, tetapi persentuhan keduanya telah memunculkan corak pemikiran rasional ala pemikir Islam yang mempertemukan dan menggabungkan antara akal dan wahyu.

Corak pemikiran rasional juga mampu mempengaruhi karakter pemikiran konstitusi dan pemerintahan pada era ini. Penggunaan akal budi rasional telah membawa kemajuan pada berbagai bidang, termasuk sains dan filsafat, yang tentunya amat berpengaruh terhadap kondisi politik dan pemerintahan. Pola paradigma hubungan antara agama dan negara pada era klasik ini lebih cenderung pada paradigma simbiosa mutualis. Hubungan yang harmonis dan saling menopang antara Islam sebagai agama dan ajaran hidup, dengan negara sebagai sebuah lembaga politik.

Pada perkembangannya, seiring dengan perkembangan dunia di luar wilayah kekuasaan umat Islam, muncul berbagai kekuatan yang mulai menggempur kekuatan umat Islam yang mulai melemah. Ditandai dengan mulainya serangan pasukan salibiyah, dari daratan Eropa, hingga penyerangan bangsa Tartar (Mongol) pada era akhir kekhalifahan dinasti Abbasiyah, pada permulaan abad 13 M. Pada pertengahan abad $13 \mathrm{M}$ inilah mulai disebut dengan era pertengahan Islam. Pada abad ini pula mulai muncul penghilangan - untuk menghindari kata kemunduran - peradaban umat Islam, mulai dari bangunan yang dihancurkan, perpustakaan yang dibakar, hingga pembunuhan tokoh-tokoh Islam.

Meski era ini sering disematkan kata kelam, tetapi era pertengahan Islam ini juga memiliki corak tersendiri, baik dalam pemikiran politik \& kenegaraan, ataupun dalam pemikiran agama. Pemikiran Islam tersebut tidak bisa dipungkiri, telah mampu lolos dan bertahan dalam dinamika waktu dan realita yang berubah. Tulisan ini disusun untuk mejawab pertanyaan besar yaitu:

${ }^{5}$ Harun Nasution. Islam Rasional, 7. 
bagaimanakah karakter pemerintahan pada dunia Islam di era abad pertengahan?

Pembahasan dalam artikel ini menggunakan pendekatan sejarah. Dengan pendekatan tersebut diharapkan mampu memilah karakter pemikiran, khususnya dalam bidang konstitusi dan pemerintahan pada masa tersebut. Pemilihan pendekatan sejarah dipilih karena panjangnya masa dan banyaknya kejadian yang timbul dan saling berpengaruh terhadap perkembangan pemikiran konstitusi dan pemerintahan era pertengahan Islam.

\section{B. Pembahasan}

Pembahasan tentang abad pertengahan Islam sering kali diawali dengan terma kemunduran. Kurun waktu $1250 \mathrm{M}$ hingga $1500 \mathrm{M}$ sering disebut sebagai era kemunduran peradaban umat Islam. Masa tersebut ditandai dengan runtuhnya kekuasan dinasti Abbasiyah, dan pelbagai serangan kekuatan asing, sering disebut sebagai kemunduran peradaban Islam. Akan tetapi, pada titik ini, penulis merasa penggunaan terma kemuduran dalam peradaban kurang tepat. Karena dalam perjalanan sebuah peradaban yang berkaitan dengan perjalanan waktu yang terus bergulir maju, yang terdapat hanya penurunan pencapaian karena berbagai faktor, eksternal dan internal.

Meminjam istilah Nurcholish Madjid, yang terjadi adalah devaluasi pencapaian, atau maksimal hanya bisa disebut sebagai kemerosotan pencaiapan dalam berbagai bidang, termasuk sains dan politik. Lebih lanjut, dalam pergulatan peradaban umat Islam dengan dinamika realita perdaban dunia di luar wilayah kekuasaan umat Islam, ada beberapa karakteristik yang terlihat menonjol dalam bidang konstitusi dan pemerintahan.

\section{Dari Desentralisasi menuju Disintegrasi}

Desentralisasi pemerintahan sejatinya telah dimulai pada abad $9 \mathrm{M}$, salah satu contohnuya, pada era pemerintahan Harun Ar-Rasyid. Meninggalnya guberbur Afrika Utara, Al-Qahir, 
menyebabkan khalifah Harun Ar-Rasyid khawatir atas ancaman dari dinasi Idrisi di wilayah tersebut. Pada saat itu, Harun ArRasyid menunjuk Ibrahim bin Aghlab sebagai amir di Tunis di bawah kekuasaan Abbasiyah. Ibrahim diwajibkan menyetor upeti 140.000 dinar setiap tahun kepada khalifah. Sebagai timbal balik, Ibrahim mengajukan persyaratan sebagai imbalan berupa otonomi. $^{6}$

Lebih lanjut, di wilayah Mesir, diangkat seorang Wali untuk wilayah Mesir yang bernama Ahmad ibnu Thulun. Pada perkembangannya, kebijakan khalifah desentralisasi dinasti Abbasiyah ini, selain menunjukkan kebijaksanaan dalam pemeritahan, tetapi pada sisi lain menurunkan bahkan melemahkan pengaruh dinasti Abbasiyah di wilayah-wilayah tertentu.

Pada awal abad ke-13 Masehi, dinasti Abbasiyah memasuki 4 khalifah terakhir; An-Nasir 1180 - 1225 M, Al-Zahir 1225 - 1226 M, Al-Muntasir 1226 - 1242 M, dan Al-Mu'tasim 1242 - 1258 M. Pada dinasti Abbasiyah, awalnya dibentuk pembagian wilayah sebagai bentuk desentralisasi kekuasaan Islam. Seperti penunjukan amir (gubernur) di wilayah-wilayah strategis kantong kekuatan umat Islam.

Dalam perkembangannya, pada era Abbasiyah, sudah muncul bibit disintegrasi dari pada pemangku kekuasan wilayah masing-masing. Hasan Ibrahim Hasan dalam bukunya AnNudzum al-Islamiyyah, menyebutkan bahwa terjadinya khalifah yang terbilang banyak. Abbasiyah di Bagdad, Fathimiyyah di Mesir, Amawiyyah di Andalus, dan Muwahiddin di Magribi. Tetapi semua itu tidak memenuhi fungsi khalifah yang sebenarnya sebagai penguasa dan pemersatu bagi seluruh dunia Islam. ${ }^{7}$

"Dengan banyaknya bilangan khalifah dalam satu masa ini maka jabatan khalifah tidak memenubi fungsi yang sebenarnya. Tidak lagi menjadi pemimpin rohani yang menguasai selurub dunia Islam,

${ }^{6}$ Imam Sukardi, Puncak Kebahagiaan Al-Farabi. Yogyakarta: Penerbit Ombak, 48.

7 Zainal Abidin Ahmad, Sejarah Islam dan Umatnya Sampai Sekarang. Jakarta: Bulan Bintang, 1977, 44. 
tetapi hanya semata-mata penguasa duniawi dalam wilayah kekuasaannya. Dengan demikian semenjak jatubnya ibu kota Baghdad, hilanglah fungsi khalifah menurut arti sebenarnya yang tradisional itu."

Disintegrasi dunia Islam ini juga diakui oleh Albert Hourani dalam bukunya The History of Arab Peoples, bahwa pada era kekhalifan Abbasiyah telah mengalami disintegrasi hingga akhir kekuasannya. Hal positif yang dibawa pada era disintegrasi ini adalah persinggungan dan penyebaran budaya Arab Islam dengan dunia luar.' Secara tidak langsung persinggungan budaya Arab - Islam dengan dunia luar juga mendorong munculnya corak pemikiran politik dan ketatanegaraan.

2. Munculnya Dinasti - Dinasti yang Bercorak Kebangsaan

Pada era pertengahan Islam ini, juga mulai muncul dinasti-dinasti yang bercorak kebangsaan. Agha Mahdi Husain, dalam bukunya The Rise of Muhammad bin Tughluq, menyatakan, bahwa di saat kehancuran dinasti Abbasiyah ada 5 kesultanan yang muncul dan menonjolkan kebangsaannya selama dalam kurun waktu 1206 - 1526 M: 1. Mamluk (1206 - 1290 M); 2. Khaljis $(1290-1320 \mathrm{M})$; 3. Thuglug $(1320-1413 \mathrm{M})$; 4. Sayyidi $(1414-1451 \mathrm{M})$; dan 5 . Lodis $(1451-1526 \mathrm{M}) .^{10}$

3. Daftar Dinasti Penting di Era Pertengahan Islam ${ }^{11}$

\begin{tabular}{|l|l|l|}
\hline Tahun & Dinasti & Wilayah \\
\hline $749-1258 \mathrm{M}$ & Abbasiyah & Baghdad \\
\hline $1077-1307 \mathrm{M}$ & Saljuq of Rum & $\begin{array}{l}\text { Bagian tengah Turki, } \\
\text { meluas ke bagian timur }\end{array}$ \\
\hline $1130-1269 \mathrm{M}$ & Almohads & Maghrib, Spanyol \\
\hline
\end{tabular}

${ }^{8}$ Ibid.

${ }^{9}$ Albert Hourani, The History of Arab Peoples. New York: Warner Book, 1991,199.

10 Zainal Abidin Ahmad, Sejarah Islam dan Umatnya Sampai Sekarang, 85.

11 Albert Hourani, The History of Arab Peoples, 489. 


\begin{tabular}{|c|c|c|}
\hline $1169-1260 \mathrm{M}$ & Ayyubids & $\begin{array}{l}\text { Maghrib, Egypt, Sebagian } \\
\text { barat dari Arabia }\end{array}$ \\
\hline $1228-1574 \mathrm{M}$ & Hafsids & $\begin{array}{lll}\text { Tunisia, } & \text { Bagian } \\
\text { Aljazair } & & \\
\end{array}$ \\
\hline $1229-1454 \mathrm{M}$ & Rasulid & Yaman \\
\hline $1250-1517 \mathrm{M}$ & Mamluk & Mesir, Syria \\
\hline $1256-1336 \mathrm{M}$ & Ilkhanids & Iran, Iraq \\
\hline $1281-1922 \mathrm{M}$ & Ottomans & $\begin{array}{l}\text { Turki, Syria, Egypt, Cyprus, } \\
\text { Tunisia, Aljazair, Bagian } \\
\text { barat Arab }\end{array}$ \\
\hline $1370-1506 \mathrm{M}$ & Timurid & Asia Tengah, Iran \\
\hline $1501-1732 \mathrm{M}$ & $\begin{array}{l}\text { Safavids } \\
\text { (Safawiyah) }\end{array}$ & Iran \\
\hline $1511-1628 \mathrm{M}$ & Sa'did & Maroko \\
\hline $1526-1858 \mathrm{M}$ & Mughals & India \\
\hline $1631 \mathrm{M}$ & Alawis & Maroko \\
\hline 1746- sekarang & Saudi & $\begin{array}{l}\text { Bagian tengah Arab, meluas } \\
\text { ke bagian barat }\end{array}$ \\
\hline
\end{tabular}

Munculnya dinasti yang menonjolkan kebangsaan, semakin menambah faktor disintegrasi kekuasaan kekhalifahan. Terlebih, pasca serangan dan gempuran militer pasukan bangsa Tartar yang dipimpin pertama kali (berhasil mengalahkan kekuatan Abbasiyah di Bagdad) oleh Gengis Khan. Serangan dahsyat bangsa Tartar dimulai pada tahun 1220 M, kemudian Gengis Khan terus menyerbu ke kota Bukhara yang mampu meluluh-lantakkan kota beserta isinya. ${ }^{12}$

Khalifah terakhir Abbasiyah, Al-Mu'tasim benar-benar takluk dengan kekuatan Gengis Khan, kota Bagdad sebagai pusat pemerintahan dan peradaban dinasti Abbasiyah luluh lantak pada tahun $1258 \mathrm{M}$ oleh pasukan Tartar. Khalifah terakhir Abbasiyah dibantai beserta para pengikutnya. Hal ini menandai selesainya masa dinasti Abbasiyah. Pasukan Tartar melanjutkan invansi

12 Zainal Abidin Ahmad. Sejarah Islam dan Umatnya Sampai Sekarang, 137. 
menuju Mesir. Pasukan Tartar dihadapi oleh dinasti Mamluk yang pada waktu itu menguasai wilayah Mesir. Pada tahun 1261, dibawah pimpinan Sultan Baybars berhasil mengalahkan dan memukul mundur pasukan Tartar. Pada titik ini, dinasti Mamluk mendapat prestis yang cukup tinggi dan amat diperhitungkan dalam bidang politik dan kekuatan negara. Memanfaatkan situasi ini, dinasti Mamluk mencoba melebarkan sayap politiknya dengan invansi untuk meraih prestis secara agama. Sultan Baybars melakukan invansi dan klaim wilayah hingga dua kota suci di Hijaz: Makkah dan Madinah. Hingga menyematkan gelar "khadi $>m$ al-h\} aramayn" pada dirinya. ${ }^{13}$

Sultan Baybars juga cukup baik dalam manuver politik untuk membuat kesultanan Mamluk menjadi semakin kuat, barisan elit militernya diberi posisi strategis sebagai elit politik. Sultan Baybars juga menyadari bahwa pada saat itu, kekuasaan politik juga membutuhkan legalitas spritual. Bagi orang Sunni pada saat itu, sultan bukan suatu jabatan politis yang berdiri sendiri, tetapi perlu pengesahan keagamaan. Oleh sebab itu, sultan harus dilantik oleh khalifah.

Demi kepentingan tersebut, Sultan Baybars mengangkat Al-Muntasir sebagai keturunan terakhir Abbasiyah yang melarikan diri ke Syria menjadi khalifah. Khalifah "boneka" tersebut akhirnya memberikan pengesahan kepada Sultan Baybars sebagai sultan untuk wilayah Mesir, Syria, Hijaz, dan daerah aliran sungai Eufrat. ${ }^{14}$ Sultan Baybars juga memperkuat hubungan diplomatik dengan penguasa Islam lainnya, salah satunya dengan Sultan Muhammad bin Thugluq dari kesultanan Delhi (India).

Pada perkembangannya, hingga akhir era abad pertangahan Islam, hanya ada 4 dinasti yang menonjolkan kebangsaannya yang benar-benar kuat dan berpengaruh. Dinasti tersebut adalah:

13 Bernard G. Weiss \& Arnold H. Green. A Survey of Arab History. Cairo: The American University in Cairo Press, 1995, 202.

14 Abd. Rahim Yunus \& Abu Haif, Sejarah Islam Pertengahan. Yogyakarta: Penerbit Ombak, 2013, 30. 
a. Mamluk yang berpusat di Mesir $(1250-1517 \mathrm{M})$.

b. Usmani yang berpusat di Turki (1281 - 1922 M).

c. Safawiyah (Safavids) berpusat di Persia (1501 - 1732 M).

d. Mughal berpusat di India (1526-1858 M).

Pada artikel ini, penulis mencoba mengambil sample perkembangan politik dan pemerintahan dari 3 (tiga) dinasti besar tersebut.

Pertama, Dinasti Usmani. Dinasti Usmani pada perkembangan sejarah abad pertengahan, sudah melakukan sistemasi pemerintahan dengan mengangkat seorang perdana menteri, seperti pada masa kesultanan Urhan I (1326 M), dengan sebutan "Shadr A'dzam". Di bawah perdana menteri terdapat gubernur yang bergelar "pasya". Pasya membawahi para pembantu gubernur yang disebut dengan Al-Sanaziq atau AlAlawiyah. Sedangkan untuk pemegang jabatan-jabatan penting, dinasti Usmani sudah mulai tidak dibedakan antara Turki dan non-Turki, muslim dan non-muslim, meski khusus untuk orang yang tidak memeluk agama Islam, sebagai formalitas, harus masuk Islam sebelum menerima jabatan. ${ }^{15}$ Pada perkembangannya, timbul tradisi yang bersifat aristokratif dalam sistem pemerintahan pada dinasti Usmani.

Akan tetapi, pada awal abad ke 18, pada era kekuasaan Sultan Mahmud II (1730 M), tradisi yang bersifat aristokratif ini dirombak. Sultan Mahmud selalu tampil dalam upacara-upacara resmi kerajaan. Dengan ini, Sultan Mahmud sedang menciptakan absolutisme baru dengan gaya pendekatan ala barat modern (modern occident). ${ }^{16}$ Sultan Mahmud II juga memberikan pembatasan kekuasaan para gubernur atau penguasa-penguasa di daerah, yang mana, pada dasarnya Sultan Mahmud II sedang memindahkan kekuasaan absolut dari daerah menuju pusat. Jabatan Shadr A'dzam sebagai pelaksana pemerintahan dihapuskan, diganti dengan membentuk Baskevil (perdana

${ }^{15}$ Ibid. 144.

${ }^{16}$ Ibid. 149. 
menteri) yang membawahi menteri (vikils) untuk urusan dalam negeri, luar negeri, keuangan, dan pendidikan.

Kedua, dinasti Safawiyah yang berpusat di Iran. Pada permulaannya, dinasti ini memiliki pemerintahan teokratik. Pejabat tertinggi negara disebut dengan "wakil an-nafs humayun", wakil sah dalam urusan politik dan keagamaan. Jabatan ini pertama kali dipegang Qizilbasy dari suku Syamlu yang sangat berkuasa di kalangan militer. ${ }^{17}$

Ketiga, dinasti (kerajaan) Mughal di India. Pemerintahan pada dinasti ini menggunakan sistem monarki, dipimpin oleh seorang raja. Kebijakan kerajaan tentang agama, selalu bergantung pada raja yang berkuasa. Seperti halnya pada kekuasaan Sultan Akbar (1556 - 1605 M), Sultan Akbar cukup toleran dan mempertimbangkan keberadaan suku dan agama yang beragam di daerah kekuasaannya.

Untuk itu, Sultan Akbar menghentikan penghancuran kuil-kuil Hindu. Sultan Akbar juga membangun aliansi dengan suku Rajput, kemudian Sultan Akbar juga mempoklamirkan dirinya sebagai Imam Adil dan Amirul Mukminin. Ibu kotanya dinamakan Dar Al-Khilafah. Pada mata uang juga tertulis nama Sultan dan Khalifah. ${ }^{18}$

Pada 4 dinasti besar pada abad pertengahan Islam ini juga ditemukan satu pola dalam mempertahankan kekuasaan politik, yaitu dengan invansi dan perluasan di wilayah sekitar kekuasaan masing-masing. Hampir setiap sultan dan raja melakukan perluasan wilayah. Baik secara diplomatis, maupun secara invansi militer.

Semangat kebangsaan ini juga timbul atas dorongan dari munculnya perpustakaan dan banyaknya buku sejarah yang bersifat lokal. Contohnya, Ibn Al-Athir (1163 - 1233 M) dari Syria yang menempatkan peristiwa-peristiwa pada masa dan tempatnya (lokal) dalam kerangka sejarah universal. Di Mesir,

${ }^{17}$ Ibid. 206.

${ }^{18}$ Ibid. 278. 
sejarah oleh Al-Maqrizi (w. 1442) dan Ibn Iyas (w. 1524 M) pada periode kekuasaan dinasti Mamluk. ${ }^{19}$

\section{Paradigma Penerapan Konstitusi pada Era Pertengahan Islam: Dari Integralistik menuju Sekuleris}

Pemikiran tentang hubungan antara Islam dan penerapan konstitusi dalam Islam, secara umum ada 3 paradigma: ${ }^{20}$

1. Paradigma Integralistik. Paradigma integralistik adalah menjadikan negara sebagai lembaga politik sekaligus menjadi lembaga keagamaan.

2. Paradigma Simbiosa Mutualistik. Paradigma simbiosa mutualistik adalah agama dan negara memiliki hubungan simbiosis mutualisme, saling terkait dan menguntungkan.

3. Paradigma Sekuleris. Paradigma sekuleristik adalah pemisahan antara agama dan negara.

Pada era Mamluk, paradigma yang timbul dalam penerapan konstitusi adalah paradigma integralistik. Pada era ini ditandai dengan seperti sudah sempat disinggung pada sub pembahasan sebelumnya kesadaran Sultan Baybars dengan pemahaman mayoritas Sunni bahwa Sultan harus mendapat legitimasi keagamaan. Dan pada kelanjutannya, dinasti Mamluk menggunakan sistem monarki, keberadaan pengganti Sultan (raja) ditunjuk melalui adanya putra mahkota.

Pada titik inilah Ibnu Taymiyyah tampil sebagai pengkritik bentuk negara yang diterapkan oleh penguasa dinasti Mamluk. Ibnu Taymiyyah menyatakan bahwa mengatur kepentingan hidup manusia secara umum adalah tugas besar dari agama, sebab tanpa kekuasaan negara yang berdaulat, agama tidak bisa berdiri tegak." Melalui karyanya, As-Siyasah Asy-Syar'iyyah, Ibnu Taymiyyah mencoba menawarkan gagasan paradigma simbiosa mutualistik antara agama dan negara. Yang mana, pada masa tersebut tertolak oleh para penguasa Mamluk yang menggunakan sistem monarki.

19 Albert Hourani, The History of Arab Peoples, 201.

20 Abd. Halim, Relasi Islam Politik dan Kekuasaan. Yogyakarta: LkiS, 2013, 47. 
Lain daripada dinasti Mamluk di Mesir, pada dinasti Safawiyah di Iran, sesudah kekuasaan Ismail I, terlihat ada gerakan pemisahan antara kepentingan kenegaraan dan kepentingan keagamaan. Pada titik ini, terjadi pergeseran fungsi dan peranan pejabat-pejabat tersebut. Jabatan wakil sudah tidak begitu kuasa lagi. Demikian pula shadr yang pada akhirnya hanya mengurus administrasi wakaf. ${ }^{21}$

Sedangkan pada dinasti Usmani, setelah era Mahmud II yang melakukan sentralisasi (kembali) kekuasaan dengan pembentukan perdana menteri yang membawahi menteri-menteri yang mengatur urusan pemerintahan, kekuasaan yudikatif dipindahkan ke tangan Syaikhul Islam. Akan tetapi, Syaikhul Islam ini hanya mengurus permasalahan yang berkaitan dengan hukum syari'at. Sedangkan hukum pemerintah diserahkan kepada Dewan Perancang Hukum untuk mengaturnya. Pada titik ini, dinasti Usmani sudah mulai membedakan antara urusan agama dan urusan pemerintahan. ${ }^{22}$ Masa inilah, menjadi sebuah embrio sekulerisme di masa akhir dinasti Usmaniyah (Ottoman), yang kemudian dipoklamirkan oleh Kemal At-Tatturk.

\section{Kesimpulan} berikut:

Dari pemaparan di atas dapat disimpulkan hal-hal sebagai

Terma kemunduran pada era abad pertengahan Islam perlu dikritisi dan perlu dikaji kembali. Mengingat pencapaian pada era ini juga tidak stagnan dan berhenti. Meski sempat kehilangan beberapa wilayah kekuasaan, tetapi perlahan mulai bisa direbut kembali melalui usaha dinasti-dinasti pada era abad pertengahan.

Corak pemikiran agama yang tradisionalis - teologis mempengaruhi pemikiran dalam konstitusi dan pemerintahan pada era Abad tengah yang cenderung menggunakan sistem monarki absolut. Munculnya disintegrasi kekuasaan pada kekhalifan Abbasiyah dan munculnya dinasti-dinasti yang menonjolkan

\footnotetext{
${ }^{21}$ Abd. Rahim Yunus \& Abu Haif, Sejarab Islam Pertengahan, 206.
}

${ }^{22}$ Ibid., 150. 
Spiritualis, vol. 4, no. 2, September 2018|188

kebangsaan sebagai dampak dari disintegrasi kekuasaan era Abbasiyah serta serangan-serangan dari kekuatan asing. Paradigma yang muncul pada era abad pertengahan Islam ini adalah, sebuah dinamika paradigma mulai dari paradigma integralistik, menuju paradigma sekuleristik. 
Spiritualis, vol. 4, no. 2, September 2018|189

\section{DAFTAR PUSTAKA}

Ahmad, Zainal Abidin. Imu Politik Islam IV: Sejarah Islam dan Umatnya Sampai Sekarang. Jakarta: Bulan Bintang, 1977.

Hourani, Albert. The History of Arab Peoples. New York: Warner Book, 1991.

- Arabic Thought in The Liberal Age 1798 - 1939. Cambridge: Oxford University Press, 1998.

Madjid, Nurcholish. Agama dan Negara dalam Islam Telaah aras Fiqh Siyasy Sunni, Kumpulan Antologi Makalah/Artike Yayasan Paramadina. Jakarta: Penerbit Paramadina, 1995.

Syadzali, Munawir. Islam dan Tata Negara, Ajaran, Sejarah, dan Pemikiran. Jakarta: Penerbit Universitas Indonesia, 1990.

Nasution, Harun. Islam Rasional. Bandung: Mizan, 1995.

Pembaharuan dalam Islam: Sejarah Gerakan dan Pembaharuan. Jakarta: Bulan Bintang, 1996.

Sukardi, Imam. Puncak Kebahagiaan (Al-Farabi). Yogyakarta: Pustaka Pelajar, 2005.

Yunus, Abd. Rahim \& Abu Haif. Sejarah Islam Pertengahan. Yogyakarta: Penerbit Ombak, 2013. 